Article

\title{
Examining the Infractions Causing Higher Rates of Suspensions and Expulsions: Racial and Ethnic Considerations
}

\author{
Craig J. Forsyth ${ }^{1}{ }^{*}$, Holly Howat ${ }^{1}$, Lai K. Pei ${ }^{1}$, York A. Forsyth ${ }^{2}$, Gary Asmus ${ }^{1}$ and \\ Billy R. Stokes ${ }^{1}$
}

1 Picard Center, The University of Louisiana, Lafayette, PO Box 42730, Lafayette, LA 70504-2730, USA

2 Political Science, The University of New Orleans, 2000 Lakeshore Drive, New Orleans, LA 701116, USA

* Author to whom correspondence should be addressed; E-Mail: cjf5714@louisiana.edu; Tel.: +1-337-482-5372; Fax: +1-337-482-5694.

Received: 25 February 2013; in revised form: 6 March 2013 / Accepted: 14 March 2013 / Published: 20 March 2013

\begin{abstract}
This study investigated school discipline infractions leading to suspensions and expulsions in Louisiana to determine patterns and trends, particularly among racial/ethnic groups. Discipline incident data rather than student discipline data were used to provide a more accurate reflection of the number of infractions and dispositions occurring. Findings included that black students and American Indian students had a higher percentage of out-of-school suspensions and were more likely to commit an infraction in the violent discipline infractions category, but the overwhelming majority of offenses for all groups were for non-violent and non-drug offenses. Links to juvenile delinquency and zero tolerance policies are discussed.
\end{abstract}

Keywords: discipline problem; suspension/expulsion rate; ethnicity/race

\section{Introduction}

During the last 40 years, school suspension and expulsion rates in the United States have increased dramatically from $3.7 \%$ in 1974 to $6.8 \%$ in 2006, not including in-school suspensions [1-3]. When considering the development of juvenile delinquency, suspension and expulsion rates are key factors to consider, because of their association to two interrelated factors: delinquency and educational 
outcomes. Suspension and expulsion, particularly penalties in which education is also suspended, are related to delinquency, truancy, dropping out, poor performance in school and poorly performing schools [4-8].

Most theories of delinquency see schools, particularly school discipline, as a contributing factor to juvenile delinquency [9]. Research has found that when juvenile offenders are unable to perform satisfactorily in school, they become disruptive and are subsequently suspended/expelled and, eventually, may drop out. The relationship between dropouts and delinquency is strong [10]. Some researchers contend that suspension and expulsion are, in most cases, ultimately rooted in poverty. Using these remedies only perpetuates the condition and the behaviors it attempts to punish. Low socioeconomic status (SES) youth are the most likely to be unsuccessful in a school setting [11]. Early negative experiences in school set in motion a cascade of disadvantage, which negatively influence youth as they transition to adulthood [12].

Risk behaviors for juvenile delinquency have their roots in the early school years and should be identified at the earliest age possible in order to maximize the possibility of positive outcomes [13-15]. Truancy is often the first sign of trouble and the most powerful predictor of delinquent behavior. Further, it is viewed as one of the top ten education-related problems in America. [16,17]. Unfortunately, schools often respond to a child's truancy problem with disciplinary actions that include exclusion of the child from school, which can exacerbate the potential for further absences and disengagement [18]. Because suspended/expelled students miss instructional time, frequent infractions and dispositions reduce students' ability to learn [19]. Early truancy can be predictive of future delinquency [20]. Attendance problems among first graders have been shown to significantly influence violent behavior, even as much as 25 years later [21]. Researchers, which examined data from 37 states, found a strong relationship between rates of suspension/expulsion and juvenile incarceration. The study also found racial disparities in school discipline and juvenile incarceration. When students are removed from school, they are more likely to engage in a variety of high risk behaviors than students who are attending. [22,23]

In 1994, President Bill Clinton signed the Gun Free Schools Act [24], which provides schools with additional funding if they enact zero tolerance policies for weapons on campus. Under the Federal Gun-Free Schools Act, local educational agencies that receive Federal funding are required to expel any student who either brings a firearm to school or possesses a firearm at school. The period was for a period of not less than one year. The CAO of the school system could adjust the penalty on a case by case basis. This discretion in crafting disciplinary codes produced codes that were too vague to serve as a guide. This eventually led to zero tolerance policies for a host of discipline infractions. Minor infractions, like dress code violations, could have severe consequences if repeated by the student. These policies collided with another trend, the accountability movement. The Unsafe School Choice Option of the No Child Left Behind Act mandates that students attending schools labeled persistently dangerous be allowed to transfer to a safe school. [25] Each state is allowed to devise a policy to define a persistently dangerous school. CAOs of schools will go to extremes to avoid this label. This combination along with shocking acts of violence in America's schools have put the nation in a panic mode and enforced the idea that maintaining the safety of schools must be one of the country's highest priorities. Each of these isolated cases of mass violence at schools catches the nation's attention and 
reinforces the idea that a school environment must have a zero-tolerance policy if it wishes to avoid a disaster.

More recently, these zero tolerance policies have been called into question, and more research is being conducted to determine the potential negative effects for students, schools and the community at large with high levels of student suspensions and expulsions. There is also a particular emphasis on investigating the impact on minority students. [26-29] African-American students are now nearly three-times as likely to be suspended or expelled as their white peers [1]. For student aged children, particularly those who live in high crime areas, school is the safest place to be.

The purpose of this study is to investigate school discipline infractions leading to suspensions and expulsions in Louisiana to determine patterns and trends. A specific interest in differences among four racial/ethnic groups is a key feature of this study. The following research questions are considered:

1. What is the pattern of suspensions and expulsions among racial/ethnic groups in Louisiana public schools during the 2008-2009 school year?

2. What types of infractions result in suspensions and expulsions in Louisiana public schools during the 2008-2009 school year?

3. What infraction patterns exist among racial/ethnic groups in Louisiana public schools during the 2008-2009 school year?

4. What specific infractions tend to result in suspensions and expulsions in Louisiana public schools during the 2008-2009 school year?

5. What differences between racial/ethnic groups are noted among the specific infractions that tend to result in suspensions and expulsions in Louisiana public schools during the 2008-2009 school year?

\section{Methods}

For this study, the researchers used enrollment and disciplinary rates calculated for this study based on 2008-2009 data reported by districts to the Louisiana Department of Education. Sample data was restricted to all public K-12 students enrolled in traditional schools statewide, i.e., students assigned to alternative schools were not considered. Further, sample data did not include students who attend private or parochial schools (approximately $20 \%$ of the school-age child population in Louisiana). It should also be noted that children attending private schools were overwhelmingly white (approximately 85\%). Discipline records included information on the disciplinary date, infraction, disposition, as well as the student's gender, ethnicity, poverty level (i.e., eligibility for free or reduced lunch) and grade level. The data used in this study are incident data rather than student data. This means that individuals contribute differently to the data, as some students will commit one infraction, another will commit ten infractions and another student will commit zero infractions. Therefore, this study focused on total suspension and expulsions during the 2008-2009 school year. Most previous research looked at the number of students suspended at least once. This method can underestimate the frequency of suspensions and expulsions as a discipline option, because many students are suspended and/or expelled more than once in a school year. Further, the incidence data analysis methods used in this study is a better indicator of the instructional time students lose, which is an often unstated issue surrounding infractions. 
According to the Louisiana Department of Education, student discipline infractions are divided into eight categories, which are disobedience, safety, substance abuse, vandalism, theft, violence, truancy and miscellaneous. There are six categories of discipline dispositions, which are: in-school suspension, suspension to an alternate site, out-of-school suspension, in-school expulsion, expulsion to an alternate site and out-of-school expulsion. In Louisiana, suspension is defined as a temporary removal of a student from the regular education setting for at least one day. The removal could be to an alternative setting within the school, an alternative site on a different campus or from all participation in any school. Expulsion is defined in different ways in Louisiana [30]. The most common definition is a removal from all regular school settings for a period of not less than one school semester, during which time the school board shall place the pupil in an alternative setting within the school, in an alternative site on a different campus or remove the student from all school activities. Generally, in-school suspensions are for the more minor infractions and out-of-school expulsions are for the most severe infractions. Some discipline infractions within the discipline infraction category of violence are felonies and may result in incarceration. In cases of incarceration, the discipline disposition type is out-of-school expulsion.

The sample distribution of the data is shown in Table 1. In 2008-2009, the sampled student population was distributed as follows: black $(\mathrm{N}=421,058 ; 48.00 \%$; males $=218,405$; females $=$ 202,653); white $(\mathrm{N}=409,707 ; 46.70 \%$; males = 214,022; females = 195,685); Hispanic $(\mathrm{N}=27,485$; $3.13 \%$; males = 14,139; females = 13,346); Asian/Pacific Islanders $(\mathrm{N}=11,988 ; 1.37 \%$; males = 6,199; females = 5,789); Native American $(\mathrm{N}=7,000 ; 0.80 \%$; males = 3,649; females $=3,351)$. There were more males students ( $\mathrm{N}=456,414 ; 52.03 \%)$ than female students $(\mathrm{N}=420,824 ; 47.97 \%)$ in the sample data; a trend consistent with all ethnic groups.

Table 1. Population distribution by ethnic group and by gender.

\begin{tabular}{|c|c|c|c|}
\hline Ethnic Group & Frequency & Male & Female \\
\hline Native American & $\begin{array}{c}7,000 \\
(0.80 \%)\end{array}$ & 3,649 & 3,351 \\
\hline Asian/Pacific Islander & $\begin{array}{c}11,988 \\
(1.37 \%)\end{array}$ & 6,199 & 5,789 \\
\hline Black & $\begin{array}{c}421,058 \\
(48.00 \%)\end{array}$ & 218,405 & 202,653 \\
\hline Hispanic & $\begin{array}{c}27,485 \\
(3.13 \%)\end{array}$ & 14,139 & 13,346 \\
\hline White & $\begin{array}{c}409,707 \\
(46.70 \%)\end{array}$ & 214,022 & 195,685 \\
\hline Totals & 877,238 & $\begin{array}{c}420,824 \\
(52.02 \%)\end{array}$ & $\begin{array}{c}456,414 \\
\text { (47.98\%) }\end{array}$ \\
\hline
\end{tabular}

\section{Findings}

The results of this research are organized in Tables 2 through 4. These tables represent discipline dispositions, not student numbers. The authors of the present study feel that the use of student data is too conservative and underestimates the frequency of the use of suspension and expulsion. Incident data better reflects the loss of instructional time. In general Table 2 provides a breakdown of discipline 
dispositions types by race/ethnic groups. Table 3 presents information on the eight discipline infraction categories by race/ethnic group. Finally, Table 4 gives results on the specific infraction codes that make up a discipline infraction category. This information in this table is also broken down by race/ethnic group. Below are answers to the research questions posed for this study.

What is the pattern of suspensions and expulsions among racial/ ethnic groups in Louisiana public schools during the 2008-2009 school year? Black students have the highest number and percentage for each of the six discipline disposition codes from in-school suspension to out-of-school expulsion. While black students comprise $48 \%$ of the sampled school population, $69.45 \%$ of the dispositions reported for this study are to black students. Conversely, white students make up the second largest race in Louisiana, with $46.70 \%$ of the sampled school population, but they only have $27.88 \%$ of the total dispositions. Other races are within $2 \%$ variation between their percentage of the total population and the percentage of total dispositions attributed to that race/ethnic group. Looking at this data another way and recalling that this is incidence data, not the number of students, it should not be surprising that black students have the highest disposition to the population ratio (54.49), since all literature indicates this is a problem. In recent research, Hispanics are generally seen as having a high ratio, but in this population, they are fourth (20.72) among the five groups for the ration of infraction to population. Asian/Pacific Islander student to disposition ratio is low at 10.39, and American Indian/Alaskan Native students are 26.99. Finally, white students fall in the middle, with a ration of 22.48 .

Table 2. Suspensions/expulsion type by race/ethnicity.

\begin{tabular}{|c|c|c|c|c|c|c|c|c|}
\hline Ethnicity & $\begin{array}{l}\text { In-School } \\
\text { Suspension }\end{array}$ & $\begin{array}{c}\text { Suspension } \\
\text { To Alternate } \\
\text { Site } \\
\end{array}$ & $\begin{array}{c}\text { Out-of- } \\
\text { School } \\
\text { Suspension } \\
\end{array}$ & $\begin{array}{l}\text { In-School } \\
\text { Expulsion }\end{array}$ & $\begin{array}{c}\text { Expulsion } \\
\text { To Alternate } \\
\text { Site } \\
\end{array}$ & $\begin{array}{c}\text { Out-of- } \\
\text { School } \\
\text { Expulsion } \\
\end{array}$ & $\begin{array}{c}\text { Totals } \\
\text { Infractions }\end{array}$ & $\begin{array}{c}\text { Sample } \\
\text { Population by } \\
\text { Race/Ethnicity }\end{array}$ \\
\hline $\begin{array}{c}\text { American } \\
\text { Indian/ } \\
\text { Alaskan } \\
\text { Native }\end{array}$ & $\begin{array}{c}N=763 \\
(40.39 \%)\end{array}$ & $\begin{array}{l}N=187 \\
(9.90 \%)\end{array}$ & $\begin{array}{c}\mathrm{N}=917 \\
(48.54 \%)\end{array}$ & $\begin{array}{c}N=1 \\
(0.05 \%)\end{array}$ & $\begin{array}{l}N=16 \\
(0.84 \%)\end{array}$ & $\begin{array}{c}N=5 \\
(0.26 \%)\end{array}$ & $\begin{array}{c}N=1,889 \\
(0.57 \%) \\
{[26.99]}\end{array}$ & $\begin{array}{c}N=7,000 \\
\{0.80 \%\}\end{array}$ \\
\hline $\begin{array}{l}\text { Asian/ } \\
\text { Pacific } \\
\text { Islander }\end{array}$ & $\begin{array}{c}N=696 \\
(55.91 \%)\end{array}$ & $\begin{array}{c}N=129 \\
(10.36 \%)\end{array}$ & $\begin{array}{c}N=396 \\
(31.81 \%)\end{array}$ & $\begin{array}{c}N=3 \\
(0.24 \%)\end{array}$ & $\begin{array}{l}\mathrm{N}=14 \\
(1.12 \%)\end{array}$ & $\begin{array}{c}N=7 \\
(0.56 \%)\end{array}$ & $\begin{array}{c}N=1245 \\
(0.38 \%) \\
{[10.39]}\end{array}$ & $\begin{array}{c}N=11,988 \\
\{1.37 \%\}\end{array}$ \\
\hline Black & $\begin{array}{c}N=90,194 \\
(39.31 \%)\end{array}$ & $\begin{array}{c}N=29,005 \\
(12.64 \%)\end{array}$ & $\begin{array}{c}N=104,964 \\
(45.75 \%)\end{array}$ & $\begin{array}{l}N=394 \\
(0.17 \%)\end{array}$ & $\begin{array}{c}N=3,391 \\
(1.48 \%)\end{array}$ & $\begin{array}{c}N=1,495 \\
(0.65 \%)\end{array}$ & $\begin{array}{c}\mathrm{N}=229,443 \\
(69.45 \%) \\
{[54.49]}\end{array}$ & $\begin{array}{c}\mathrm{N}=421,058 \\
\{48.00 \%\}\end{array}$ \\
\hline Hispanic & $\begin{array}{l}N=3,108 \\
(54.57 \%)\end{array}$ & $\begin{array}{l}N=392 \\
(6.89 \%)\end{array}$ & $\begin{array}{l}N=2,091 \\
(36.72 \%)\end{array}$ & $\begin{array}{c}\mathrm{N}=4 \\
(0.07 \%)\end{array}$ & $\begin{array}{l}N=56 \\
(0.98 \%)\end{array}$ & $\begin{array}{l}N=44 \\
(0.77 \%)\end{array}$ & $\begin{array}{c}N=5,695 \\
(1.72 \%) \\
{[20.72]}\end{array}$ & $\begin{array}{c}\mathrm{N}=27,485 \\
\{3.13 \%\}\end{array}$ \\
\hline White & $\begin{array}{c}N=45,012 \\
(48.86 \%)\end{array}$ & $\begin{array}{c}N=5,335 \\
(5.79 \%)\end{array}$ & $\begin{array}{c}N=40,054 \\
(43.48 \%)\end{array}$ & $\begin{array}{l}N=149 \\
(0.16 \%)\end{array}$ & $\begin{array}{c}\mathrm{N}=1,080 \\
(1.2 \%)\end{array}$ & $\begin{array}{l}N=490 \\
(5.31 \%)\end{array}$ & $\begin{array}{c}N=92,120 \\
(27.88 \%) \\
{[22.48 \%]}\end{array}$ & $\begin{array}{c}\mathrm{N}=409,707 \\
\{46.70 \%\}\end{array}$ \\
\hline Totals & $\mathrm{N}=139,773$ & $N=35,048$ & $N=148,422$ & $\mathrm{~N}=551$ & $\mathrm{~N}=4,557$ & $\mathrm{~N}=2,041$ & $\mathrm{~N}=330,392$ & $\mathrm{~N}=877,238$ \\
\hline
\end{tabular}


Table 3. Discipline infraction category by race/ethnicity.

\begin{tabular}{|c|c|c|c|}
\hline Ethnicity & Discipline Categories & $\mathbf{N}$ & Percent of totals \\
\hline American Indian/Alaskan Native & Disobedience & 1,305 & 69.08 \\
\hline \multirow[t]{6}{*}{1,889} & Substance Abuse & 28 & 1.48 \\
\hline & Vandalism/Theft & 26 & 1.37 \\
\hline & Theft & 17 & 0.89 \\
\hline & Violence & 230 & 12.17 \\
\hline & Truancy & 164 & 8.68 \\
\hline & Misc. & 119 & 6.29 \\
\hline Asian/Pacific Islander & Disobedience & 679 & 54.54 \\
\hline \multirow[t]{6}{*}{1,245} & Substance Abuse & 33 & 2.66 \\
\hline & Vandalism/Theft & 14 & 01.12 \\
\hline & Theft & 26 & 02.09 \\
\hline & Violence & 138 & 11.08 \\
\hline & Truancy & 250 & 20.08 \\
\hline & Misc. & 105 & 08.43 \\
\hline Black & Disobedience & 151,938 & 66.22 \\
\hline \multirow[t]{7}{*}{229,443} & Safety & 318 & 0.14 \\
\hline & Substance Abuse & 1,956 & 0.85 \\
\hline & Vandalism/Theft & 1,507 & 0.66 \\
\hline & Theft & 2,766 & 1.21 \\
\hline & Violence & 37,505 & 16.35 \\
\hline & Truancy & 22,079 & 9.62 \\
\hline & Misc. & 11,374 & 4.95 \\
\hline Hispanic & Disobedience & 3,337 & 58.59 \\
\hline \multirow[t]{7}{*}{5,695} & Safety & 9 & 0.16 \\
\hline & Substance Abuse & 87 & 1.53 \\
\hline & Vandalism/Theft & 67 & 1.18 \\
\hline & Theft & 74 & 1.30 \\
\hline & Violence & 618 & 10.85 \\
\hline & Truancy & 1,067 & 18.74 \\
\hline & Misc. & 436 & 7.65 \\
\hline White & Disobedience & 58,197 & 63.18 \\
\hline \multirow[t]{7}{*}{92,120} & Safety & 139 & 0.15 \\
\hline & Substance Abuse & 2,788 & 3.03 \\
\hline & Vandalism/Theft & 1,102 & 1.19 \\
\hline & Theft & 1,138 & 1.23 \\
\hline & Violence & 10,069 & 10.93 \\
\hline & Truancy & 10,231 & 11.11 \\
\hline & Misc. & 8,456 & 9.18 \\
\hline
\end{tabular}


Table 4. Specific discipline infraction category by race/ethnicity.

\begin{tabular}{|c|c|c|c|c|c|c|c|}
\hline $\begin{array}{l}\text { Specific Discipline } \\
\text { Infraction }\end{array}$ & $\begin{array}{l}\text { Discipline } \\
\text { Infraction } \\
\text { Categories }\end{array}$ & $\begin{array}{l}\text { American } \\
\text { Indian / } \\
\text { Alaskan } \\
\text { Native }\end{array}$ & $\begin{array}{l}\text { Asian / } \\
\text { Pacific } \\
\text { Islander }\end{array}$ & Black & Hispanic & White & Totals \\
\hline Willful disobedience & Disobedience & 570 & 303 & 62,658 & 1468 & 23,882 & 88,881 \\
\hline $\begin{array}{l}\text { Treats an authority } \\
\text { with disrespect }\end{array}$ & Disobedience & 212 & 79 & 29,755 & 479 & 9,345 & 39,658 \\
\hline $\begin{array}{l}\text { Makes an unfounded } \\
\text { charge against } \\
\text { authority }\end{array}$ & Disobedience & 1 & 0 & 587 & 12 & 219 & 819 \\
\hline $\begin{array}{l}\text { Uses profane and/or } \\
\text { obscene language }\end{array}$ & Disobedience & 111 & 69 & 13,858 & 304 & 6,388 & 20,730 \\
\hline $\begin{array}{l}\text { Is guilty of immoral or } \\
\text { vicious practices }\end{array}$ & Disobedience & 40 & 27 & 4,028 & 139 & 1,942 & 6,206 \\
\hline $\begin{array}{l}\text { Is guilty of conduct or } \\
\text { habits injurious to } \\
\text { his/her associates }\end{array}$ & Disobedience & 111 & 44 & 9,572 & 229 & 4,700 & 14,656 \\
\hline $\begin{array}{l}\text { Disturbs the school } \\
\text { habitually or violates } \\
\text { any rule }\end{array}$ & Disobedience & 260 & 157 & 31,480 & 706 & 11,721 & 44,324 \\
\hline $\begin{array}{l}\text { Violates traffic and } \\
\text { safety regulations }\end{array}$ & Safety & 0 & 0 & 318 & 9 & 139 & 466 \\
\hline $\begin{array}{l}\text { Uses or possesses any } \\
\text { controlled dangerous } \\
\text { substances governed } \\
\text { by the Uniform } \\
\text { Controlled Dangerous } \\
\text { Substances Law, in } \\
\text { any form }\end{array}$ & $\begin{array}{l}\text { Substance } \\
\text { Abuse }\end{array}$ & 18 & 17 & 946 & 38 & 853 & 1,872 \\
\hline $\begin{array}{l}\text { Uses or possess } \\
\text { tobacco or lighter }\end{array}$ & $\begin{array}{l}\text { Substance } \\
\text { Abuse }\end{array}$ & 9 & 10 & 856 & 38 & 1,671 & 2,584 \\
\hline $\begin{array}{l}\text { Uses or possesses } \\
\text { alcoholic beverages }\end{array}$ & $\begin{array}{l}\text { Substance } \\
\text { Abuse }\end{array}$ & 1 & 6 & 154 & 11 & 264 & 436 \\
\hline $\begin{array}{l}\text { Cuts, defaces, or } \\
\text { injures any part of } \\
\text { public school } \\
\text { buildings/ vandalism }\end{array}$ & $\begin{array}{l}\text { Vandalism/ } \\
\text { Theft }\end{array}$ & 17 & 5 & 808 & 36 & 600 & 1,466 \\
\hline $\begin{array}{l}\text { Writes profane and/or } \\
\text { obscene language or } \\
\text { draws obscene } \\
\text { pictures }\end{array}$ & $\begin{array}{l}\text { Vandalism/ } \\
\text { Theft }\end{array}$ & 8 & 8 & 672 & 30 & 486 & 1,204 \\
\hline Arson & $\begin{array}{l}\text { Vandalism/ } \\
\text { Theft }\end{array}$ & 0 & 1 & 10 & 0 & 5 & 16 \\
\hline $\begin{array}{l}\text { Criminal damage to } \\
\text { property }\end{array}$ & $\begin{array}{l}\text { Vandalism/ } \\
\text { Theft }\end{array}$ & 1 & 0 & 17 & 1 & 11 & 30 \\
\hline Is guilty of stealing & Theft & 17 & 26 & 2,755 & 74 & 1136 & 4,008 \\
\hline
\end{tabular}


Table 4. Cont.

\begin{tabular}{|c|c|c|c|c|c|c|c|}
\hline $\begin{array}{l}\text { Specific Discipline } \\
\text { Infraction }\end{array}$ & $\begin{array}{l}\text { Discipline } \\
\text { Infraction } \\
\text { Categories }\end{array}$ & $\begin{array}{l}\text { American } \\
\text { Indian / } \\
\text { Alaskan } \\
\text { Native }\end{array}$ & $\begin{array}{l}\text { Asian / } \\
\text { Pacific } \\
\text { Islander }\end{array}$ & Black & Hispanic & White & Totals \\
\hline Burglary & Theft & 0 & 0 & 11 & 0 & 2 & 13 \\
\hline $\begin{array}{l}\text { Possesses weapon(s) } \\
\text { prohibited under }\end{array}$ & & & & & & & \\
\hline $\begin{array}{l}\text { federal law, as defined } \\
\text { in Section } 921 \text { of Title } \\
18 \text { of the U.S. Code. }\end{array}$ & Violence & 0 & 3 & 88 & 5 & 34 & 130 \\
\hline $\begin{array}{l}\text { Possesses firearms } \\
\text { (not prohibited by } \\
\text { federal law), knives, }\end{array}$ & & & & & & & \\
\hline $\begin{array}{l}\text { or their implements, } \\
\text { which can be used as } \\
\text { weapons, the careless } \\
\text { use of which might } \\
\text { inflict harm or injury }\end{array}$ & Violence & 11 & 5 & 918 & 24 & 577 & 1,535 \\
\hline $\begin{array}{l}\text { Throws missiles liable } \\
\text { to injure others }\end{array}$ & Violence & 28 & 5 & 1,337 & 32 & 589 & 1,991 \\
\hline $\begin{array}{l}\text { Instigates or } \\
\text { participates in fights } \\
\text { while under school } \\
\text { supervision }\end{array}$ & Violence & 188 & 121 & 34,451 & 536 & 8,629 & 43,925 \\
\hline Murder & Violence & 0 & 0 & 12 & 0 & 2 & 14 \\
\hline Assault and battery & Violence & 3 & 2 & 519 & 9 & 131 & 664 \\
\hline $\begin{array}{l}\text { Rape and sexual } \\
\text { battery }\end{array}$ & Violence & 0 & 0 & 24 & 0 & 11 & 35 \\
\hline $\begin{array}{l}\text { Misappropriation with } \\
\text { violence to the person }\end{array}$ & Violence & 0 & 0 & 46 & 5 & 7 & 58 \\
\hline $\begin{array}{l}\text { Illegal carrying and } \\
\text { discharge of weapons }\end{array}$ & Violence & 0 & 0 & 7 & 0 & 2 & 9 \\
\hline $\begin{array}{l}\text { Possesses pocket knife } \\
\text { with a blade length of } \\
\text { less than } 21 / 2 \text { inches }\end{array}$ & Violence & 0 & 2 & 60 & 3 & 76 & 141 \\
\hline Serious bodily injury & Violence & 0 & 0 & 43 & 4 & 11 & 58 \\
\hline Kidnapping & Violence & 0 & 0 & 2 & 0 & 0 & 2 \\
\hline $\begin{array}{l}\text { Leaves school } \\
\text { premises or classroom } \\
\text { without permission }\end{array}$ & Truancy & 117 & 119 & 11,793 & 566 & 5,848 & 18,443 \\
\hline $\begin{array}{l}\text { Is habitually tardy } \\
\text { and/or absent }\end{array}$ & Truancy & 47 & 131 & 10,286 & 501 & 4,383 & 15,348 \\
\hline \multirow[t]{2}{*}{$\begin{array}{l}\text { Commits any other } \\
\text { serious offense }\end{array}$} & Misc. & 119 & 105 & 11,372 & 436 & 8,456 & 20,488 \\
\hline & Totals & 1,889 & 1,245 & 229,443 & 5,695 & 92,120 & 330,210 \\
\hline
\end{tabular}

A final trend can be seen in looking at the highest dispositions for each race/ethnic group. For white, Hispanic and Asian/Pacific Islander students, they were most likely to receive an in-school suspension for an infraction, followed by out-of-school suspension. Black and American 
Indian/Alaskan Native students were more likely to receive an out-of-school suspension than an in-school suspension. One hypothesis may be that the types of infractions they are committing result in more severe dispositions. Tables 3 and 4 explore that issue.

What types of infractions result in suspensions and expulsions in Louisiana public schools during the 2008-2009 school year and what infraction patterns exist among racial/ethnic groups?

As stated earlier, the Louisiana Department of Education divides infractions into eight discipline categories. In Table 3, the number of infractions for each racial/ethnic group within each of the discipline categories is presented. As can be seen in this table, there is much similarity between all racial/ethnic groups. For each of the five ethnic groups, disobedience is the largest discipline infraction category, with over 50 percent of all infractions for each racial/ethnic group categorized as such. For three of the groups, whites, Asian/ Pacific Islanders and Hispanics, truancy and violence are the second and third highest discipline categories respectively. However, for black and American Indian/Native Alaskan students, violence is the second highest category, followed by truancy. The catch-all category, miscellaneous, is the fourth highest for all groups. Infractions in this category are defined as "any other serious offense." Safety infractions represent the smallest number of infractions, with each group having less than $1 \%$ of the total infractions.

What specific infractions tend to result in suspensions and expulsions in Louisiana public schools during the 2008-2009 school year, and what differences are noted between racial/ethnic groups? Table 4 provides a more detailed look at the 32 discipline infractions broken down by infraction code and racial/ethnic group. In the most common category, disobedience, every racial/ethnic group had willful disobedience as the top discipline infraction. There is currently no uniform definition for this infraction in Louisiana. Recent legislation to operationally define this discipline code in each Louisiana school district was vetoed by the governor. In the safety category, only black, white and Hispanic students committed infractions, which includes violations of traffic and safety regulations. For the substance abuse category, Hispanics and whites were more likely to have committed infractions related to tobacco, while other race/ethnicity groups were more likely to have committed infractions related to illegal drugs. All other categories, including violence, have similar racial/ethnic breakdowns, with the exception of vandalism and truancy. Asian/Pacific Islander students were more likely to vandalize by writing profanity rather than damaging property, and they were more likely to be habitually absent rather than leave school without permission in the truancy category.

To summarize the findings, this data indicates that black students, and often American Indian/Native Alaskan students, show little difference in the specific infraction patterns from other racial/ethnic groups, with the exception of the higher infractions related to illegal drugs than whites or Hispanics. However, once infractions are grouped into categories, black and American Indian/Native Alaskan students have violent infractions as their second highest category, as opposed to truancy for the other racial/ethnic groups. Further, these two racial/ethnic groups are more likely to receive an out-of-school suspension that in-school suspension. The other interesting pattern was the differences in discipline data among Asian/Pacific Islander students. While only a small portion of the overall student population, these students were less likely to have a discipline infraction that resulted in a suspension or expulsion. Additionally, while their infraction categories were similar to other racial/ethnic groups, the specific infractions were often different. For example, Asian/Pacific Islander students were more likely to be habitually absent than to leave campus. 


\section{Conclusions}

Any analysis, which compares discipline infractions and/or criminal offenses by students of different races/ethnicities should not accept a literal interpretation of the numbers. Much research has documented that behavior alone could not explain differences in how police might treat black and white youth [31]. One should therefore not accept these differences as factual indicators of behavior. Self-report studies indicate that middle SES youth commit a higher portion of infractions and offenses than to which they are held accountable [32]. Research indicates that lower SES youth of all ethnicities are more likely to have brushes with the police than their middle SES counterparts [33]. Some researchers claim SES status is the culprit [34]. Since black youth are vastly overrepresented in the lower SES categories, the cause may not make a difference (race or poverty), but the effect is the same. Other researchers [35] found that even when controlling for SES, black students had significantly higher rates of suspensions/expulsions. In addition, minor misbehaviors, which fall under broadly and subjectively defined categories, are the majority of offenses, and black students are more likely to be suspended for these infractions than other ethnic groups [29]. The most frequently applied discipline infraction category is disobedience, and it is also the most subjective. The seven specific discipline infractions within this category have no precise definition; indeed, their titles defy specificity. These seven infractions are the major reason for overall higher differences for black students. When infractions are specifically defined, most differences either decrease, disappear or other groups take the lead.

Teachers may exhibit the same prejudices as police. Ferguson [29] vividly describes the processes in school in which there were two tracks for students. One was mostly white, in which students were tracked into professional futures. The other track, which was predominately black, placed black boys in crime careers.

...the school labeling practices and the exercise of rules operated as part of a hidden curriculum to marginalize and isolate black male youths in disciplinary spaces and brand them as criminally inclined ([29], p. 2).

Once the school labeled these youth as troublemakers, they attempted to make a name for themselves within the guise of the label "bad boys".

...the performance of masculinity through dramatic performances and disruptions in class, through making a name through fighting, as a strategy for recouping a sense of self as creative, powerful, competent in the face of the tedium of the school's workday ([29], p. 223).

The importance of determining disproportionate use of strong discipline dispositions (suspensions and expulsion) among racial/ethnic groups becomes apparent when considering the rise of zero tolerance policies in the recent past. As noted earlier, suspension and expulsions have almost doubled in the past four decades, with zero tolerance policies seen as the primary factor for this increase. In an attempt to provide the most effective learning environments and to maintain safety, school systems developed a zero tolerance policy approach to school discipline [36]. This approach to school discipline imposes immediate and often long-term removal from school for a broad range of school code violations, including dress code violations, truancy and violent behavior. The policy has led to deeply divided 
opinions and debate on school discipline. Those supporting the zero tolerance philosophy and practice offer many reasons why a frequent resort to out-of-school suspension/expulsion is critical for maintaining order and discipline in the schools [37]. They argue that suspensions/expulsions remove disorderly students and deter other students from bad behavior. This improves the school environment so that well-behaving students can learn without distractions. Recent research [1] regarding the zero tolerance policy has raised serious challenges about both the fairness and effectiveness of these policies. Additionally, despite two decades of implementation of zero-tolerance disciplinary policies and their application to non-violent and non-serious misbehaviors, there is no evidence that this frequent reliance on removing misbehaving students improves student behavior or school safety [23].

Pei, Forsyth, Teddlie, Asmus and Stokes [38] demonstrated that race/ethnicity is associated with student disciplinary dispositions. In their study, while controlling for four levels of school ethnic diversity, they found that black students compared to other student ethnic groups had higher rates of infractions at every level of diversity. This current study continued to add to the growing body of research indicating blacks (and American Indians/Native Alaskans in this study) are recorded as committing more infractions and receive more severe dispositions than other racial/ethnic groups in Louisiana. Other researchers $[4,22,23,35]$ beyond Louisiana have similar data and similar concerns with the data. Additional, deeper research along racial/ethnic groups that links the specific discipline infraction to its disposition may provide more information on the disproportionate use of suspension and expulsion among black students, particularly where precise definitions of infractions do not exist [39,40]. Readers should be reminded of one fact of this data: regardless of comparative differences, the overwhelming majority of offenses for all groups were for non-violent and non-drug offenses.

\section{References and Notes}

1. Tony Fabelo, Michael Thompson, and Martha Plotkin. Breaking Schools' Rules: A Statewide Study of How School Discipline Relates to Students' Success and Juvenile Justice Involvement. New York: Council of State Governments Justice Center, 2011.

2. American Psychological Association Zero Tolerance Task Force. “Are Zero Tolerance Policies Effective in the Schools? An Evidentiary Review and Recommendations.” American Psychologist 63 (2008): 852-62.

3. US Department of Education Office of Civil Rights, 2006 Data Collection, Washington, DC: US Department of Education, 2008.

4. "Suspension, Expulsions, and Health Related Exclusions. Maryland Public Schools, 2006-2007.” Maryland State Department of Education, Division of Accountability and Assessment, Baltimore, MD, USA, 2007.

5. Richard Arum, and Irenee Beattie. "High School Experience and the Risk of Adult Incarceration." Criminology 37 (1999): 515-30.

6. Richard Felson, and Jeremy Staff. "Explaining the Academic Performance-Delinquency Relationship.” Criminology 44 (2006): 299-320.

7. Craig J. Forsyth, Gary Asmus, Billy Stokes, and York A. Forsyth. “A Research Note on School Effects: Low performing schools and delinquency.” The International Journal of Sociological Research 3 (2010): 81-86. 
8. Craig J. Forsyth, Gary Asmus, Billy Stokes, and York A. Forsyth. "Comparing Performance Test Scores of Juvenile Delinquents with the General Population of Students.” Deviant Behavior 31 (2010): 303-13.

9. Donald J. Shoemaker. Theories of Delinquency: An Examination of Explanations of Delinquent Behavior. New York: Oxford University Press, 2000.

10. LaMar Empey, and Steven Lubeck. Explaining Delinquency. Lexington, MA: Lexington Books, 1971.

11. Don Weatherburn, and Lind Bronwyn. Delinquent-Prone Communities. New York: Cambridge University Press, 2001.

12. Zeng-yin Chen, and Howard Kaplan. "School Failure in Early Adolescence and Status Attainment in Middle Adulthood: A longitudinal study.” Sociology of Education 76 (2003): 110-27.

13. Craig J. Forsyth, Gary Asmus, York A. Forsyth, Billy Stokes, and Mike Mayne. "Child Delinquents: Examining the market for criminal futures.” Deviant Behavior32 (2011): 441-50.

14. Craig J. Forsyth, Gary Asmus, York A. Forsyth, and Billy Stokes. "Comparing Male and Female Juvenile Delinquents.” The International Journal of Crime, Criminal Justice and Law 4 (2009): $69-75$.

15. Craig J. Forsyth, DeAnn Kalich, Gary Asmus, Billy Stokes, and York A. Forsyth. "Examining Characteristics and Placement of Youth.” The International Journal of Crime, Criminal Justice and Law 3 (2008):169-76.

16. Joy Dryfoos. Adolescents at Risk: Prevalence and Prevention. New York: Oxford University Press, 1990.

17. Eileen Garry. Truancy: First Step to a Lifetime of Problems. Juvenile Justice Bulletin. Washington, DC: Office of Juvenile Justice and Delinquency Prevention, 1996.

18. Gale Morrison, and Barbara D’Incau. "Developmental and Service Trajectories of Students with Disabilities Recommended for Expulsion from School.” Exceptional Children 66 (2000): 257-72.

19. Charles Greenwood, Betty Horton, and Cheryl Utley. "Academic Engagement: Current Perspectives on Research and Practice.” School Psychology Review 31 (2002): 328-49.

20. C.N. Tait. Strategies for Adolescence: Turning it Around for Middle-School Students. Clemson, S.C.: National Dropout Prevention Center, 2004.

21. Joan McCord, and Margaret Ensminger. "Multiple Risks and Comorbidity in an African American Population.” Criminal Behavior and Mental Health 7 (1997): 339-52.

22. Russell Skiba, Robert Michael, Abra Nardo, and Reece Peterson. "The Color of Discipline: Sources of racial and Gender Disproportionality in School Punishment.” The Urban Review 34 (2002): 317-42.

23. Russell Skiba, and Mark Karega Rausch. "Zero Tolerance, Suspension, and Expulsion: Questions of Equality and Effectiveness.” In Handbook for Classroom Management: Research, Practice, and Contemporary Issues. Edited by Carolyn Evertson, and Carol Weinstein. Mahwah, NJ: Lawrence Erlbaum Associates, 2006, 1063-89.

24. See 18 U.S.C.§ 922 and Safe and Drug-Free Schools and Communities-Gun-Free Schools Act, 20 USCA §7151, 2006.

25. No Child Left Behind Act, Unsafe Schools Choice Option (USCO), title IX, part E, subpart 2, section 9532, 2002. 
26. Advancement Project \& Civil Rights Project. Opportunties Suspended: The Devastating Consequences of Zero Tolerance and School Discipline Policies. Cambridge: Harvard Civil Rights Project, 2000.

27. John Wallace, Jr., Sara Goodkind, Cynthia Wallace, and Jerald Bachman. "Racial, Ethnic, and Gender Differences in School Discipline Among U.S. High School Students: 1995-2005.” Negro Educational Review 59 (2008): 47-62.

28. Johanna Wald, and Daniel Losen. Deconstructing the School to Prison Pipeline: New Direction for Youth Development. San Francisco: Jossey-Bass, 2003.

29. Ann Arnett Ferguson. Bad Boys: Public Schools in the Making of Black Masculinity. Ann Arbor, MI: The University of Michigan Press, 2000.

30. See 2006 Louisiana Laws-RS 17:416—Discipline of Pupils; suspension; expulsion. Justia US Law, 2006

31. Jeffrey Reiman. The Rich Get Richer and the Poor get Prison: Class, Ideology and Criminal Justice. New York, NY: Pearson/Allyn\& Bacon, 2007.

32. Delbert Elliot, and Suzanne Ageton. "Reconciling Race and Class Differences in Self-reported and Official Estimates of Delinquency.” American Sociological Review 45 (1980): 95-110.

33. Elizabeth Brown, and M. Males. "Does Age or Poverty Level Best Predict Criminal Arrest and Homicide Rates? A Preliminary Investigation.” Justice Policy Journal 8 (2011): 1-30.

34. bell hooks. Where We Stand. New York: Routledge, 2000.

35. Shi-Chang Wu, William Pink, Robert Crain, and Oliver Moles. Students Suspension: A Critical Reappraisal. The Urban Review 14 (1982): 245-303.

36. Judith Brown-Dianis. "Stepping back from zero tolerance.” Educational Leadership 69 (2011): 24-28.

37. Kenneth Trump. Stopping School Violence. New York: Aspen Publishers, 1998.

38. Lai K. Pei, Craig J. Forsyth, Susan Teddlie, Gary Asmus, and Billy Stokes. "Bad Behavior, Ethnicity, and Level of School Diversity.” Deviant Behavior 34 (2013): 1-10.

39. Maurice Taylor, and Gerald Foster. Bad Boys and Schools Suspensions: Public Policy Implications for Black Males. Sociological Inquiry 56 (1986): 498-506.

40. Alicia C. Insley. Suspending and Expelling Children From Educational Opportunity: Time To Reevaluate Zero Tolerance Policies. American University Law Review 50 (2001): 1039-74.

(C) 2013 by the authors; licensee MDPI, Basel, Switzerland. This article is an open access article distributed under the terms and conditions of the Creative Commons Attribution license (http://creativecommons.org/licenses/by/3.0/). 